\title{
FAKTOR RISIKO KEJADIAN TB PARU DI PUSKESMAS HUTARAKYAT SIDIKALANG
} TAHUN 2017

\author{
Sehra Banu ${ }^{1}$, Rahmadani Sitepu ${ }^{2}$, Refi Sulistiasari ${ }^{2}$ \\ ${ }^{1}$ Magister Fakultas Kesehatan Masyarakat, Universitas Sumatera Utara \\ 2 Fakultas Kedokteran, Universitas Islam Sumatera Utara
}

\begin{abstract}
ABSTRAK
Tuberkulosis (TB) merupakan penyakit yang masih menjadi masalah utama kesehatan secara global di dunia dan menyebabkan tingkat morbiditas pada jutaan orang setiap tahunnya. Tujuan penelitan ini adalah menganalisis faktor risiko kejadian TB Paru di Puskesmas Hutarakyat Sidikalang. Jenis penelitian ini analitik dengan rancangan penelitian case control.Jumlah sampel pada penelitian ini adalah 44 kasus dan 44 kontrol yang diperoleh dengan menggunakan purposive sampling.

Hasil penelitian ini menunjukkan analisis faktor umur terhadap TB Paru $p=0,003$, analisis faktor status gizi terhadap TB Paru $p=0,001$, analisis faktor penghasilan terhadap TB Paru $p=0,002$, analisis faktor pendidikan terhadap TB Paru $p=0,184$, analisis faktor kebiasaan merokok terhadap TB Paru $p=0,001$, analisis faktor kepadatan hunian terhadap TB Paru $p=0,001$, analisis faktor pencahayaan hunian terhadap TB Paru $p=0,034$, analisis faktor jenis kelamin terhadap TB Paru $p=1,00$, analisis faktor suku terhadap TB Paru $p=0,01$. Sehingga dapat disimpulkan bahwa terdapat pengaruh yang signifikan antara umur, status gizi, penghasilan, kebiasaan merokok, kepadatan hunian, pencahayaan hunian, dan suku terhadap kejadian TB Paru. Saran kepada semua pihak baik dinas, puskesmas dan masyarakat saling bekerjasama dalam hal mencegah penularan penyakit TB Paru.
\end{abstract}

\section{Kata Kunci : TB Paru, Analisis, Faktor Risiko}

\section{Pendahuluan}

Tuberkulosis (TB) merupakan penyakit yang masih menjadi masalah utama kesehatan secara global di dunia dan menyebabkan tingkat morbiditas pada jutaan orang setiap tahunnya.Menurut World Health Organization (WHO) TB adalah penyakit infeksi yang disebabkan oleh Mycobacterium tuberculosis. (Saputra, L. 2013)

TB adalah suatu penyakit infeksi kronik yang sudah sangat lama dikenal pada manusia, misalnya dia dihubungkan dengan tempat tinggal di daerah urban, lingkungan yang padat, dibuktikan dengan adanya penemuan kerusakan tulang vertebrata toraks yang khas TB dari kerangka yang digali di Heidelberg dari kuburan zaman neolitikum, begitu juga penemuan yang berasal dari mummi dan ukiran dinding piramid di mesir kuno pada tahun 20004000 SM. Hipokrates telah memperkenalkan terminologi phthisis yang diangkat dari bahasa Yunani yang menggambarkan tampilan TB ini.

Robert Koch mengidentifikasi basil tahan asam M.tuberculosis untuk pertama kali sebagai bakteri penyebab TB ini. Konsep dari pada imunitas yang didapat (acquired immunity) diperlihatkan dengan pengembangan vaksin $T B$, satu vaksin yang sangat sukses, yaitu vaksin Bacillius Calmette Guerin (BCG) dibuat dari suatu strain Mikrobakterium Bovis, vaksin ini ditemukan oleh Albert Calmette dan Camille Guerin di Institut Pasteur Perancis dan diberikan pertama kali ke manusia pada tahun 1921.( Amin, Z., Bahar, A. 2014)

Pada Annual TB Report WHO 2015 mengenai Tuberculosis Control in The South-East Asia Region (SEAR) tahun 2013, SEAR menyumbang 38\% (3,4 juta insiden kasus TB) dari insiden kasus TB di dunia dan 39\% kematian (440.000 kematian) akibat TB di dunia, dengan estimasi 4,5 juta prevalensi 
kasus TB. Dari 3,4 juta insiden kasus TB yang terjadi di wilayah SEAR tahun 2013, India merupakan negara penyumbang insiden terbanyak yaitu $62,4 \%$ diikuti Indonesia 13,7\% peringkat kedua, dan peringkat ketiga yaitu Bangladesh 10,4\%.( Saputra, L. 2013)

Indonesia merupakan negara pertama di negara-negara dengan beban TB yang tinggi di wilayah Asia Tenggara yang berhasil mencapai target Millenium Development Goals (MDGs) untuk TB pada tahun 2006, yaitu $70 \%$ penemuan kasus baru BTA positif dan $85 \%$ kesembuhan. Saat ini Indonesia telah turun dari urutan ketiga menjadi urutan kelima negara dengan TB tertinggi di dunia.Indonesia sekarang berada pada ranking kelima negara dengan TB tertinggi di dunia.Estimasi prevalensi TB semua kasus adalah sebesar 660,000, dan estimasi insidensi berjumlah 430,000 kasus baru per tahun.Jumlah kematian akibat TB diperkirakan 61,000 kematian per tahunnya.( Saputra, L. 2013)

Berdasarkan jumlah penduduk tahun 2012, diperhitungkan sasaran penemuan kasus baru TB Paru BTA (+) di Provinsi Sumatera Utara adalah sebesar 21.145 jiwa, dan hasil cakupan penemuan kasus baru TB Paru BTA $(+)$ yaitu 17.459 kasus atau $82,57 \%$. Angka ini mengalami peningkatan dibanding dengan tahun 2011 yaitu $76,57 \%$ dan 2010 yaitu 68,86\%. (Depkes RI. 2012)

Berdasarkan latar belakang tersebut peneliti bermaksud mengkaji ulang mengenai Faktor Risiko Kejadian TB Paru di Puskesmas Huta Rakyat Sidikalang Tahun 2017. Berdasarkan uraian latar belakang masalah tersebut, maka muncul pokok permasalahan yaitu Faktor Risiko Kejadian TB Paru di Puskesmas Hutarakyat Sidikalang Tahun 2017?.

\section{Metode Penelitian}

Penelitian menggunakan studi
observasional dengan jenis desain
penelitian studi kasus kontrol (case
control study). Kasus adalah seseorang
dengan gejala klinis TB danyang sudah
didiagnosis melalui Tes Sputum dan Foto

Toraks di Puskesmas Huta Rakyat Sidikalang pada November 2017 hingga Desember 2017, sedangkan kontrol adalah seseorang yang datang ke puskesmas saat peneliti mengambil data pada kasus dengan jumlah dan waktu yang sama di Puskesmas Hutarakyat Sidikalang.

Penelitian ini dilaksanakan di Puskesmas Huta Rakyat Sidikalang selama 1 bulan, yaitu pada bulan November hingga Desember 2017. Peneliti mengambil data di Puskesmas Hutarakyat Sidikalang karena disana terdapat banyak masyarakat yang menderita TB Paru.

Penelitian ini adalah semua penderita TB Paruyang berobat di Puskesmas Hutarakyat Sidikalang pada Desember 2017 mundur ke belakang, dan sebagai kontrol adalah pasien umum yang berobat di pada tempat, bulan, dan tahun yang sama. Didapati sebanyak 54 kasus pasien TB Paru di Puskesmas Hutarakyat Sidikalang. Penelitian ini menggunakan purposive sampling, dengan menggunakan Tabel Isaac didapati kasus sebanyak 44 dan kontrol 44.

Jenis data primer yang dikumpulkan adalah umur, pendidikan, pendapatan, status gizi, merokok, kepadatan hunian, pencahayaan hunian, diperoleh dengan wawancara menggunakan kuesioner. Sedangkan untuk variabel TB menggunakan data sekunder yaitu informasi dari petugas pemegang program TB di Puskesmas tempat penelitian.

Pengambilan sampel kasus dan kontrol dilakukan di Puskesmas Hutarakyat Sidikalang juga yang bulan dan tahunnya sama dengan kasus yaitu sebanyak masing-masing 44 orang. Perbandingan jumlah sampel kasus dan kontrol adalah $1: 1$.

- Kriteria inklusi

- Pasien TB Paru di Puskesmas Huta Rakyat Sidikalang tanpa melihat riwayat pengobatan sebelumnya.

- Bersedia menjadi subyek untuk penelitian ini dan menandatangani informed consent.

- Saat diteliti, subjek sedang dalam keadaan sadar penuh. 
Pengumpulan data mencari faktorfaktor yang mempengaruhi kejadian TB Paru di Puskesmas Hutarakyat Sidikalang dengan cara kuesioner. Populasi terjangkau yang memenuhi kriteria inklusi akan diberikan penjelasan singkat mengenai penelitian. Setelah diberi penjelasan dan sesudah mengisi informed consent, peneliti akan memberikan kuesioner (terlampir) kepada responden untuk diisi. Proses pengumpulan kuesioner berlangsung selama 2-4 minggu. Proses pengumpulan data dibantu oleh petugas program TB di Puskesmas Hutarakyat Sidikalang.

Bagian rangkaian penelitian setelah pengumpulan data kemudian diolah sehingga menghasilkan informasi, yaitu dengan meneliti setiap pertanyaan yang telah dijawab dan memastikan seluruh pertanyaan terjawab lalu merubah data bentuk huruf menjadi angka atau bilangan, gunanya untuk mempermudah saat analisis data. Setelah selesai melakukan editing dan pengkodean, data diproses dengan cara memasukkan data dari kuisioner ke paket program komputer.Dilakukan pembersihan data untuk mencegah kesalahan entry data yang mungkin terjadi.

Proses pengumpulan dan pengolahan data telah dilakukan, kemudian dilanjutkan dengan analisis dengan tahapan sebagai berikut:

a. Analisis Univariat

Analisis univarat untuk mendeskripsikan karakteristik masingmasing variabel yang diteliti, bentuk tergantung jenis data, untuk data kategorik digunakan distribusi frekuensi.

b. Analisis Bivariat

Analisa bivariat dilakukan untuk mengetahui hubungan antara variabel independen dan variabel dependen. Untuk mengetahui hal itu uji yang digunakan adalah uji kai kuadrat (chi square) dan perhitungan odd ratio (OR) sehingga dapat diketahui ada dan tidak hubungan yang bermakna secara statistik dengan derajat kemaknaan 0,05 atau $a=5 \%$. iniadalah:

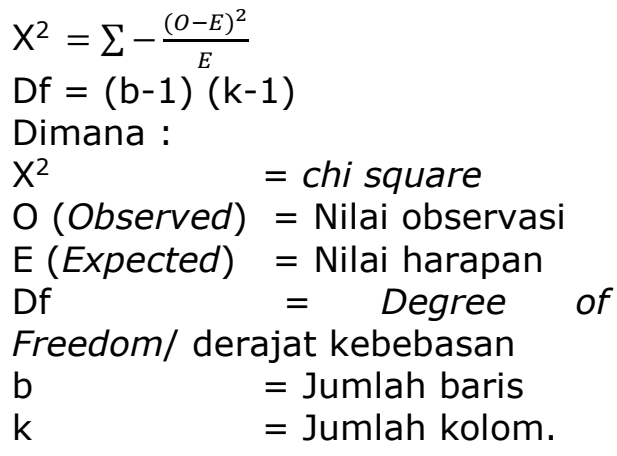

Hasil akhir uji statistik adalah untuk mengetahui keputusan uji $\mathrm{Ho}$ ditolak atau Ho gagal ditolak. Dengan ketentuan apabila $p$ value $<a(0,05)$, Maka Ho ditolak, artinya ada hubungan yang bermakna, jika $p$ value $>a$, maka Ho gagal ditolak, artinya tidak ada hubungan yang bermakna antar variabel. Didapati CI $=95 \%$.

\section{Hasil Penelitian}

Penelitian ini dilakukan di Puskesmas Hutarakyat, Kecamatan Sidikalang, Kabupaten Dairi, Provinsi Sumatera Utara. Dengan jumlah responden adalah 44 kasus dan 44 kontrol. Puskesmas Hutarakyat bersebelahan dengan rumah masyarakat, mempunyai 7 ruangan dan Puskesmas Hutarakyat memiliki jarak $\pm 3 \mathrm{~km}$ dari kota Sidikalang

\section{Analisis Univariat}

Analisis univariat berguna untuk melihat karakteristik responden kasus dan kontrol. Responden kasus adalah penderita TB Paru sedangkan kontrol adalah yang tidak TB Paru. Berdasarkan tabel 1 didapatkan bahwa responden berumur muda yang terkena TB Paru sebanyak 3 orang $(6,8 \%)$, berumur muda yang tidak terkena TB Paru sebanyak 14 orang $(31,8 \%)$, berumur dewasa yang terkena TB Paru sebanyak 41 orang $(9,2 \%)$, berumur dewasa yang tidak terkena TB Paru sebanyak 30 orang $(68,2 \%)$. 
Tabel 1 : Karakteristik responden menurut umur

\begin{tabular}{llcccc}
\hline No & $\begin{array}{c}\text { Karakteristi } \\
\mathbf{k}\end{array}$ & \multicolumn{2}{c}{ TB Paru } & \multicolumn{2}{c}{$\begin{array}{c}\text { Tidak TB } \\
\text { Paru }\end{array}$} \\
\cline { 3 - 6 } & Responden & $\mathbf{n}$ & $\mathbf{\%}$ & $\mathbf{n}$ & $\mathbf{\%}$ \\
\hline $\mathbf{1}$ & Umur & & & & \\
& Muda & 3 & 6,8 & 14 & 31,8 \\
& Dewasa & 41 & 93,2 & 30 & 68,2 \\
\hline & Total & $\mathbf{4 4}$ & $\mathbf{1 0 0}$ & $\mathbf{4 4}$ & $\mathbf{1 0 0}$ \\
\hline
\end{tabular}

Berdasarkan tabel 2 didapatkan bahwa responden yang mempunyai status gizi kurang dan terkena TB Paru sebanyak 33 orang $(75,0 \%)$, status gizi kurang dan tidak terkena TB Paru sebanyak 10 orang $(22,7 \%)$, status gizi cukup dan terkena TB Paru sebanyak sebanyak 11 orang $(25,0 \%)$, status gizi cukup dan tidak terkena TB Paru sebanyak sebanyak 34 orang(77,3\%).

Tabel 2 : Karakteristik responden menurut status gizi

\begin{tabular}{lllccc}
\hline \multirow{2}{*}{ No } & $\begin{array}{c}\text { Karakteristi } \\
\mathbf{k}\end{array}$ & \multicolumn{2}{c}{ TB Paru } & \multicolumn{2}{c}{$\begin{array}{c}\text { Tidak TB } \\
\text { Paru }\end{array}$} \\
\cline { 3 - 6 } & Responden & n & $\mathbf{\%}$ & n & \% \\
\hline $\mathbf{1}$ & Status Gizi & & & & \\
& Kurang & 33 & 75,0 & 10 & 22,7 \\
& Cukup & 11 & 25,0 & 34 & 77,3 \\
\hline & Total & $\mathbf{4 4}$ & $\mathbf{1 0 0}$ & $\mathbf{4 4}$ & $\mathbf{1 0 0}$ \\
\hline
\end{tabular}

Berdasarkan tabel 3 didapatkan bahwa responden yang berpenghasilan rendah dan terkena TB Paru sebanyak 38 orang $(86,4 \%)$, berpenghasilan rendah dan tidak terkena TB Paru sebanyak 25 orang $(56,8 \%)$, berpenghasilan tinggi dan terkena TB Paru sebanyak sebanyak 6 orang $(13,6 \%)$, berpenghasilan tinggi dan tidak terkena TB Paru sebanyak sebanyak 19 orang $(43,2 \%)$.

Tabel 3 : Karakteristik responden menurut penghasilan

\begin{tabular}{llcccc}
\hline \multirow{2}{*}{ No } & \multirow{2}{*}{$\begin{array}{c}\text { Karakteristik } \\
\text { Responden }\end{array}$} & \multicolumn{2}{c}{ TB Paru } & \multicolumn{2}{c}{ Tidak } \\
\cline { 3 - 6 } & & n & \% & n & \% \\
\hline $\mathbf{1}$ & Penghasilan & & & & \\
& Rendah & 38 & 86,4 & 25 & 56,8 \\
& Tinggi & 6 & 13,6 & 19 & 43,2 \\
\hline & Total & $\mathbf{4 4}$ & $\mathbf{1 0 0}$ & $\mathbf{4 4}$ & $\mathbf{1 0 0}$ \\
\hline
\end{tabular}

Berdasarkan tabel 4 didapatkan bahwa responden yang berpendidikan rendah dan terkena TB Paru sebanyak 31 orang $(70,5 \%)$, berpendidikan rendah dan tidak terkena TB Paru sebanyak 25 orang (56,8\%), berpendidikan tinggi dan terkena TB Paru sebanyak sebanyak 13 orang $(29,5 \%)$, berpendidikan tinggi dan tidak terkena TB Paru sebanyak sebanyak 19 orang $(43,2 \%)$.

Tabel 4 : Karakteristik responden menurut pendidikan

\begin{tabular}{llcccc}
\hline & $\begin{array}{c}\text { Karakteris } \\
\text { tik }\end{array}$ & \multicolumn{2}{c}{ TB Paru } & \multicolumn{2}{c}{$\begin{array}{c}\text { Tidak TB } \\
\text { Paru }\end{array}$} \\
\cline { 3 - 6 } & $\begin{array}{c}\text { Responde } \\
\text { n }\end{array}$ & $\mathbf{n}$ & \% & n & \% \\
\hline $\mathbf{1}$ & $\begin{array}{l}\text { Pendidikan } \\
\text { Rendah }\end{array}$ & 31 & 70,5 & 25 & 56,8 \\
& $\begin{array}{l}\text { Rendah } \\
\text { Tinggi }\end{array}$ & 13 & 29,5 & 19 & 43,2 \\
\hline & Total & $\mathbf{4 4}$ & $\mathbf{1 0 0}$ & $\mathbf{4 4}$ & $\mathbf{1 0 0}$ \\
\hline
\end{tabular}

Berdasarkan tabel 5 didapatkan bahwa responden yang merokok dan terkena TB Paru sebanyak 42 orang $(95,5 \%)$, merokok dan tidak terkena TB Paru sebanyak 24 orang (54,5\%), tidak merokok dan terkena TB Paru sebanyak sebanyak 2 orang $(4,5 \%)$, tidak merokok dan tidak terkena TB Paru sebanyak sebanyak 20 orang $(45,5 \%)$.

Tabel 5 : Karakteristik responden menurut kebiasaan merokok

\begin{tabular}{|c|c|c|c|c|c|}
\hline \multirow{2}{*}{$\begin{array}{l}\mathbf{N} \\
\mathbf{0}\end{array}$} & \multirow{2}{*}{$\begin{array}{c}\text { Karakteristi } \\
\text { k } \\
\text { Responden }\end{array}$} & \multicolumn{2}{|c|}{ TB Paru } & \multicolumn{2}{|c|}{$\begin{array}{c}\text { Tidak TB } \\
\text { Paru }\end{array}$} \\
\hline & & $\mathbf{n}$ & $\%$ & $n$ & $\%$ \\
\hline \multirow[t]{4}{*}{1} & $\begin{array}{l}\text { Kebiasaan } \\
\text { Merokok }\end{array}$ & & & & \\
\hline & Merokok & 4 & 95 & 24 & 54,5 \\
\hline & $\begin{array}{l}\text { Tidak } \\
\text { Merokok }\end{array}$ & 2 & 4 & 20 & 45,5 \\
\hline & Total & 44 & 100 & 44 & 100 \\
\hline
\end{tabular}

Berdasarkan tabel 6 didapatkan bahwa responden yang padat penghuni dan terkena TB Paru sebanyak 36 orang $(81,8 \%)$, padat penghuni dan tidak terkena TB Paru sebanyak 20 orang $(45,5 \%)$, tidak padat penghuni dan terkena TB Paru sebanyak sebanyak 8 orang $(18,2 \%)$, tidak padat penghuni dan tidak terkena TB Paru sebanyak sebanyak 24 orang $(54,5 \%)$. 
Tabel 6 : Karakteristik responden menurut kepadatan hunian

\begin{tabular}{llcccc}
\hline & $\begin{array}{c}\text { Karakteris } \\
\text { tik }\end{array}$ & \multicolumn{2}{c}{ TB Paru } & \multicolumn{2}{c}{$\begin{array}{c}\text { Tidak TB } \\
\text { Paru }\end{array}$} \\
\cline { 3 - 6 } & $\begin{array}{c}\text { Responde } \\
\text { no }\end{array}$ & $\mathbf{n}$ & \% & N & \% \\
\hline $\mathbf{1}$ & Kepadatan & & & & \\
& Hunian & & & & \\
& Padat & 36 & 81,8 & 20 & 45,5 \\
& Tidak Padat & 8 & 18,2 & 24 & 54,5 \\
\hline & Total & $\mathbf{4 4}$ & $\mathbf{1 0 0}$ & $\mathbf{4 4}$ & $\mathbf{1 0 0}$ \\
\hline
\end{tabular}

Berdasarkan tabel 7 didapatkan bahwa responden yang padat penghuni dan terkena TB Paru sebanyak 13 orang $(29,5 \%)$, padat penghuni dan tidak terkena TB Paru sebanyak 5 orang $(11,4 \%)$, tidak padat penghuni dan terkena TB Paru sebanyak sebanyak 31 orang $(70,5 \%)$, tidak padat penghuni dan tidak terkena TB Paru sebanyak sebanyak 39 orang $(88,6 \%)$.

Tabel 7 : Karakteristik responden menurut pencahayaan hunian

\begin{tabular}{llcccc}
\hline & $\begin{array}{c}\text { Karakteri } \\
\text { stik }\end{array}$ & \multicolumn{2}{c}{ TB Paru } & \multicolumn{2}{c}{$\begin{array}{c}\text { Tidak TB } \\
\text { Paru }\end{array}$} \\
\cline { 3 - 6 } & $\begin{array}{c}\text { Respond } \\
\text { en }\end{array}$ & $\mathbf{n}$ & $\%$ & $\mathbf{n}$ & $\%$ \\
\hline $\mathbf{1}$ & $\begin{array}{l}\text { Pencahay } \\
\text { aan }\end{array}$ & & & & \\
& Hunian & & & & \\
& Gelap & 13 & 29,5 & 5 & 11,4 \\
& Terang & 31 & 70,5 & 39 & 88,6 \\
\hline & Total & $\mathbf{4 4}$ & $\mathbf{1 0 0}$ & $\mathbf{4 4}$ & $\mathbf{1 0 0}$ \\
\hline
\end{tabular}

Berdasarkan tabel 8 didapatkan bahwa responden berjenis kelamin lakilaki dan terkena TB Paru sebanyak 32 orang $(72,7 \%)$, berjenis kelamin lakilaki dan tidak terkena TB Paru sebanyak 32 orang $(72,7 \%)$, berjenis kelamin perempuan dan terkena TB Paru sebanyak sebanyak 12 orang $(27,3 \%)$, berjenis kelamin perempuan dan tidak terkena TB Paru sebanyak sebanyak 12 orang $(27,3 \%)$.
Tabel 8 : Karakteristik responden menurut jenis kelamin

\begin{tabular}{|c|c|c|c|c|c|}
\hline \multirow[t]{2}{*}{$\mathbf{N}$} & \multirow{2}{*}{$\begin{array}{c}\text { Karakteris } \\
\text { tik } \\
\text { Responde } \\
\mathbf{n}\end{array}$} & \multicolumn{2}{|c|}{ TB Paru } & \multicolumn{2}{|c|}{$\begin{array}{c}\text { Tidak TB } \\
\text { Paru }\end{array}$} \\
\hline & & $\mathbf{n}$ & $\%$ & $\mathbf{N}$ & $\%$ \\
\hline \multirow[t]{4}{*}{1} & $\begin{array}{l}\text { Jenis } \\
\text { Kelamin }\end{array}$ & & & & \\
\hline & Laki-laki & 32 & 72,7 & 32 & 72,7 \\
\hline & Peremp & 12 & 27,3 & 12 & 27,3 \\
\hline & Total & 44 & 100 & 44 & 100 \\
\hline
\end{tabular}

Berdasarkan tabel 9 didapatkan bahwa responden bersuku batak toba dan terkena TB Paru sebanyak 35 orang $(79,5 \%)$, bersuku batak toba dan tidak terkena TB Paru sebanyak 35 orang $(79,5 \%)$, bersuku pak-pak dan terkena TB Paru sebanyak sebanyak 9 orang $(20,5 \%)$, bersuku pak-pak dan tidak terkena TB Paru sebanyak sebanyak 9 orang $(20,5 \%)$.

Tabel 9 : Karakteristik responden menurut suku

\begin{tabular}{llcccc}
\multicolumn{2}{c}{ No } & $\begin{array}{c}\text { Karakteris } \\
\text { tik } \\
\text { Responde } \\
\text { n }\end{array}$ & \multicolumn{2}{c}{ TB Paru } & \multicolumn{3}{c}{$\begin{array}{c}\text { Tidak TB } \\
\text { Paru }\end{array}$} \\
\cline { 3 - 6 } & \multicolumn{1}{c}{ n } & \% & N & \% \\
\hline $\mathbf{1}$ & Suku & & & & \\
& Batak Toba & 35 & 79,5 & 35 & 79,5 \\
& Pak-pak & 9 & 20,5 & 9 & 20,5 \\
\hline & Total & $\mathbf{4 4}$ & $\mathbf{1 0 0}$ & $\mathbf{4 4}$ & $\mathbf{1 0 0}$ \\
\hline
\end{tabular}

\section{Analisis Bivariat}

Analisis bivariat akan menjelaskan pengaruh antara factor risiko/determinan terhadap kejadian TB Paru. Berdasarkan tabel 4.10 didapatkan bahwa analisis factor umur terhadap kejadian TB Paru terdapat pengaruh yang signifikan antara umur muda (17-20th) dan umur dewasa (2158th) terhadap terjadinya TB Paru $p=0,003 \quad(p<0,05) \quad$ dan selanjutnya diperoleh Odds Ratio $=0,157$. 
Tabel 10 : Analisis Faktor Umur terhadap TB Paru

Tabel 12 : Analisis Faktor Pengahasilan terhadap TB Paru

\begin{tabular}{|c|c|c|c|c|c|c|}
\hline \multirow[t]{2}{*}{ Umur } & \multicolumn{2}{|c|}{ TB Paru } & \multicolumn{2}{|c|}{$\begin{array}{l}\text { Tidak TB } \\
\text { Paru }\end{array}$} & \multirow[t]{2}{*}{ Sig } & \multirow[t]{2}{*}{ OR } \\
\hline & $\mathbf{n}$ & $\%$ & $\mathbf{n}$ & $\%$ & & \\
\hline Muda & 3 & 6,8 & 14 & 31,8 & \multirow[b]{2}{*}{$\begin{array}{l}0,0 \\
03\end{array}$} & \multirow[b]{2}{*}{0,157} \\
\hline $\begin{array}{l}\text { Dewa } \\
\text { sa }\end{array}$ & 41 & 93,2 & 30 & 68,2 & & \\
\hline Total & 44 & 100 & 44 & 100 & & \\
\hline \multicolumn{7}{|c|}{$\begin{array}{l}\quad \text { Berdasarkan tabel } 4.11 \\
\text { didapatkan bahwa analisis factor status } \\
\text { gizi terhadap kejadian TB Paru terdapat } \\
\text { pengaruh yang signifikan antara gizi } \\
\text { kurang dan gizi cukup terhadap } \\
\text { terjadinya TB Paru } p=0,000 \quad(p<0,05) \\
\text { dan selanjutnya diperoleh Odds Ratio = } \\
10,200 \text {. }\end{array}$} \\
\hline & \multicolumn{4}{|c|}{$\begin{array}{l}\text { Tabel } 11: \text { Analisis } \\
\text { Status Gizi terhadap T }\end{array}$} & $\begin{array}{l}\text { s Fak } \\
\text { TB Par }\end{array}$ & $\begin{array}{l}\text { tor } \\
\text { u }\end{array}$ \\
\hline \multirow[t]{2}{*}{$\begin{array}{l}\text { Status } \\
\text { Gizi }\end{array}$} & \multicolumn{2}{|c|}{ TB Paru } & \multicolumn{2}{|c|}{$\begin{array}{c}\text { Tidak TB } \\
\text { Paru }\end{array}$} & \multirow[t]{2}{*}{ Sig } & \multirow[t]{2}{*}{ OR } \\
\hline & $\mathbf{N}$ & $\%$ & $\mathbf{n}$ & $\%$ & & \\
\hline Kurang & 33 & 75,0 & 10 & 22,7 & \multirow{2}{*}{$\begin{array}{l}0,0 \\
01\end{array}$} & \multirow{2}{*}{$\begin{array}{c}10,2 \\
00\end{array}$} \\
\hline Cukup & 11 & 25,0 & 34 & 77,3 & & \\
\hline Total & 44 & 100 & 44 & 100 & & \\
\hline
\end{tabular}

Pen

gha TB Paru Tidak TB

sila TB Paru Paru Sig OR

n

$\begin{array}{ccccccc} & \mathbf{n} & \mathbf{\%} & \mathbf{n} & \% & & \\ \text { Ren } & 38 & 86,4 & 25 & 56,8 & & \\ \text { dah } & & & & & 0,0 & 4,8 \\ & & & & & 02 & 13\end{array}$

$\begin{array}{lllll}\text { gi } & 6 & 13,6 & 19 & 43,2\end{array}$

Tot

al

$\begin{array}{llll}44 & 100 & 44 & 100\end{array}$

Berdasarkan tabel 13 didapatkan bahwa analisis factor pendidikan terhadap kejadian TB Paru tidak terdapat pengaruh yang signifikan antara pendidikan rendah dan pendidikan tinggi terhadap terjadinya TB Paru $p=0,184(p>0,05)$ dan selanjutnya diperoleh Odds Ratio $=1,812$.

Tabel 13 : Analisis Faktor Pendidikan terhadap TB Paru

\begin{tabular}{|c|c|c|c|c|c|c|}
\hline \multirow{2}{*}{$\begin{array}{l}\text { Pend } \\
\text { idika } \\
\text { n }\end{array}$} & \multicolumn{2}{|c|}{ TB Paru } & \multicolumn{2}{|c|}{$\begin{array}{c}\text { Tidak } \\
\text { TB Paru }\end{array}$} & \multirow[t]{2}{*}{ Sig } & \multirow[t]{2}{*}{ OR } \\
\hline & $\mathbf{n}$ & $\%$ & $\mathbf{n}$ & $\%$ & & \\
\hline $\begin{array}{l}\text { Rend } \\
\text { ah }\end{array}$ & 31 & $\begin{array}{c}70, \\
5\end{array}$ & 25 & $\begin{array}{c}56 \\
8\end{array}$ & 0,1 & 1,8 \\
\hline $\begin{array}{l}\text { Tingg } \\
\mathrm{i}\end{array}$ & 13 & $\begin{array}{c}29 \\
5\end{array}$ & 19 & $\begin{array}{c}43 \\
2\end{array}$ & 84 & 12 \\
\hline Total & 44 & $\begin{array}{c}10 \\
0\end{array}$ & 44 & $\begin{array}{c}10 \\
0\end{array}$ & & \\
\hline
\end{tabular}

Berdasarkan tabel 12 didapatkan bahwa analisis factor penghasilan terhadap kejadian TB Paru terdapat pengaruh yang signifikan antara penghasilan rendah dan penghasilan tinggi terhadap terjadinya TB Paru $p=0,002 \quad(p<0,05) \quad$ dan selanjutnya diperoleh Odds Ratio $=4,813$.

Berdasarkan tabel 14 didapatkan bahwa analisis factor kebiasaan merokok terhadap kejadian TB Paru terdapat pengaruh yang signifikan antara merokok dan tidak merokok terhadap terjadinya TB Paru $p=0,000 \quad(p<0,05)$ dan selanjutnya diperoleh Odds Ratio $=$ 17,500 . 
Tabel 14 : Analisis Faktor Kebiasaan Merokok terhadap TB Paru
Tabel 16 : Analisis Faktor Pencahayaan Hunian terhadap TB Paru

\begin{tabular}{|c|c|c|c|c|c|c|}
\hline \multirow[t]{2}{*}{$\begin{array}{l}\text { Kebias } \\
\text { aan } \\
\text { Merok } \\
\text { ok }\end{array}$} & \multicolumn{2}{|c|}{ TB Paru } & \multicolumn{2}{|c|}{$\begin{array}{l}\text { Tidak } \\
\text { TB Paru }\end{array}$} & \multirow[t]{2}{*}{ Sig } & \multirow[t]{2}{*}{ OR } \\
\hline & $\mathbf{n}$ & $\%$ & $\mathbf{n}$ & $\%$ & & \\
\hline $\begin{array}{l}\text { Meroko } \\
\mathrm{k}\end{array}$ & 42 & 95,5 & 24 & $\begin{array}{c}54 \\
5\end{array}$ & 0,0 & 17, \\
\hline $\begin{array}{l}\text { Tidak } \\
\text { Meroko } \\
\text { k }\end{array}$ & 2 & 4,5 & 20 & $\begin{array}{c}45 \\
5\end{array}$ & 01 & $\begin{array}{c}50 \\
0\end{array}$ \\
\hline Total & 44 & 100 & 44 & $\begin{array}{c}10 \\
0\end{array}$ & & \\
\hline
\end{tabular}

Berdasarkan tabel 15 didapatkan bahwa analisis factor kepadatan hunian terhadap kejadian TB Paru terdapat pengaruh yang signifikan antara hunian padat dan tidak padat terhadap terjadinya TB Paru $p=0,000 \quad(p<0,05)$ dan selanjutnya diperoleh Odds Ratio $=$ 5,400 .

Tabel 15 : Analisis Faktor Kepadatan Hunian terhadap TB Paru

\begin{tabular}{|c|c|c|c|c|c|c|}
\hline \multirow{2}{*}{$\begin{array}{l}\text { Kepa } \\
\text { data } \\
\text { n } \\
\text { Huni } \\
\text { an } \\
\end{array}$} & \multicolumn{2}{|c|}{ TB Paru } & \multicolumn{2}{|c|}{$\begin{array}{c}\text { Tidak } \\
\text { TB Paru }\end{array}$} & \multirow{2}{*}{ Sig } & \multirow{2}{*}{ OR } \\
\hline & $\mathbf{n}$ & $\%$ & $\mathbf{n}$ & $\%$ & & \\
\hline Padat & 36 & 81,8 & 20 & $\begin{array}{c}45 \\
5\end{array}$ & 0,0 & 5,4 \\
\hline $\begin{array}{l}\text { Tidak } \\
\text { Padat }\end{array}$ & 8 & 18,2 & 24 & $\begin{array}{c}54 \\
5\end{array}$ & 01 & 00 \\
\hline Total & 44 & 100 & 44 & $\begin{array}{c}10 \\
0\end{array}$ & & \\
\hline
\end{tabular}

Berdasarkan tabel $\quad 4.16$ didapatkan bahwa analisis factor pencahayaan hunian terhadap kejadian TB Paru terdapat pengaruh yang signifikan antara pencahayaan gelap dan pencahayaan terang terhadap terjadinya TB Paru $p=0,034 \quad(p<0,05)$ dan selanjutnya diperoleh Odds Ratio = 3,271 .

\begin{tabular}{|c|c|c|c|c|c|c|}
\hline \multirow{2}{*}{$\begin{array}{l}\text { Penc } \\
\text { ahay } \\
\text { aan } \\
\text { Huni } \\
\text { an }\end{array}$} & \multicolumn{2}{|c|}{ TB Paru } & \multicolumn{2}{|c|}{$\begin{array}{c}\text { Tidak } \\
\text { TB Paru }\end{array}$} & \multirow[t]{2}{*}{ Sig } & \multirow[t]{2}{*}{ OR } \\
\hline & $\mathbf{n}$ & $\%$ & $\mathbf{n}$ & $\%$ & & \\
\hline Gelap & 13 & 29,5 & 5 & $\begin{array}{c}11 \\
4\end{array}$ & 0,0 & 3,2 \\
\hline $\begin{array}{l}\text { Teran } \\
\mathrm{g}\end{array}$ & 31 & 70,5 & 39 & $\begin{array}{c}88 \\
6\end{array}$ & 34 & 71 \\
\hline Total & 44 & 100 & 44 & $\begin{array}{c}10 \\
0\end{array}$ & & \\
\hline
\end{tabular}

Berdasarkan tabel 17 didapatkan bahwa analisis factor jenis kelamin terhadap kejadian TB Paru tidak terdapat pengaruh yang signifikan antara jenis kelamin laki-laki dan jenis kelamin perempuan terhadap terjadinya TB Paru $p=1,00 \quad(p>0,05)$ dan selanjutnya diperoleh Odds Ratio = 1,000 .

Tabel 17 : Analisis Faktor Jenis Kelamin terhadap TB Paru

\begin{tabular}{|c|c|c|c|c|c|c|}
\hline \multirow[t]{2}{*}{$\begin{array}{l}\text { Jenis } \\
\text { Kelam } \\
\text { in }\end{array}$} & \multicolumn{2}{|c|}{ TB Paru } & \multicolumn{2}{|c|}{$\begin{array}{c}\text { Tidak } \\
\text { TB Paru }\end{array}$} & \multirow[t]{2}{*}{ Sig } & \multirow[t]{2}{*}{ OR } \\
\hline & $\mathbf{n}$ & $\%$ & $n$ & $\%$ & & \\
\hline $\begin{array}{l}\text { Laki- } \\
\text { laki }\end{array}$ & 32 & $\begin{array}{c}72, \\
7\end{array}$ & 32 & $\begin{array}{c}72 \\
7\end{array}$ & \multirow{2}{*}{$\begin{array}{c}1,0 \\
0\end{array}$} & \multirow{2}{*}{$\begin{array}{l}1,0 \\
00\end{array}$} \\
\hline $\begin{array}{l}\text { Perem } \\
\text { puan }\end{array}$ & 12 & $\begin{array}{c}27 \\
3\end{array}$ & 12 & $\begin{array}{c}27 \\
3\end{array}$ & & \\
\hline Tota & 44 & $\begin{array}{c}10 \\
0\end{array}$ & 44 & $\begin{array}{c}10 \\
0\end{array}$ & & \\
\hline
\end{tabular}

Berdasarkan tabel 4.18 didapatkan bahwa analisis factor suku terhadap kejadian TB Paru terdapat pengaruh yang signifikan antara suku batak toba dan suku pak-pak terhadap terjadinya TB Paru $\mathrm{p}=0,01(\mathrm{p}<0,05)$ dan selanjutnya diperoleh Odds Ratio = 1,000 . 
Tabel 18 : Analisis Faktor Suku terhadap TB Paru

\begin{tabular}{|c|c|c|c|c|c|c|}
\hline \multirow[t]{2}{*}{ Suku } & \multicolumn{2}{|c|}{ TB Paru } & \multicolumn{2}{|c|}{$\begin{array}{l}\text { Tidak } \\
\text { TB Paru }\end{array}$} & \multirow[t]{2}{*}{ Sig } & \multirow[t]{2}{*}{ OR } \\
\hline & n & $\%$ & $\mathbf{n}$ & $\%$ & & \\
\hline $\begin{array}{l}\text { Batak } \\
\text { Toba }\end{array}$ & 35 & 79,5 & 35 & 79,5 & \multirow[b]{2}{*}{0,01} & \multirow[b]{2}{*}{1,000} \\
\hline $\begin{array}{l}\text { Pak- } \\
\text { pak }\end{array}$ & 9 & 20,5 & 9 & 20,5 & & \\
\hline Total & 44 & 100 & 44 & 100 & & \\
\hline
\end{tabular}

\section{Pembahasan}

\section{Umur}

Analisis faktor umur terhadap kejadian TB Paru terdapat pengaruh yang signifikan antara umur muda (17-20th) dan umur dewasa (21-58th) terhadap terjadinya TB Paru $p=0,003 \quad(p<0,05)$ dan selanjutnya diperoleh Odds Ratio $=0,157$. Dengan kata lain peluang terjadinya TB Paru tidak ada pengaruh antara usia muda dan usia dewasa. Hal ini sejalan dengan penelitian Muaz di Serang tahun 2014 dan juga penelitian Rushadi et al di Sukabumi tahun 2014. (Djojodibroto, R.D. 2016)

\section{Status Gizi}

Analisis faktor status gizi terhadap kejadian TB Paru terdapat pengaruh yang signifikan antara gizi kurang dan gizi cukup terhadap terjadinya TB Paru $p=0,001 \quad(p<0,05)$ dan selanjutnya diperoleh Odds Ratio $=10,200$. Dengan kata lain peluang terjadinya TB Paru 10,200 kali lebih besar pada responden dengan gizi kurang dibanding responden dengan gizi cukup. Gizi merupakan salah satu faktor yang sangat berpengaruh terhadap kesehatan seseorang, semakin terpenuhinya gizi seseorang maka semakin kecil kemungkinan terjadinya penularan penyakit. $\mathrm{Hal}$ ini sejalan dengan penelitian Muaz di Serang tahun 2014 dan juga Prihanti et al di Kediri tahun 2015. (Himawan, A.B., Suharyo, H., Suprihati, 2015)

\section{Penghasilan}

Analisis faktor penghasilan terhadap kejadian TB Paru terdapat pengaruh yang signifikan antara penghasilan rendah dan penghasilan tinggi terhadap terjadinya TB Paru $p=0,002 \quad(p<0,05)$ dan selanjutnya diperoleh Odds Ratio = 4,813. Dengan kata lain peluang terjadinya TB Paru 4,813 kali lebih besar pada responden dengan penghasilan rendah dibanding responden dengan penghasilan tinggi. Penghasilan berhubungan dengan faktor gizi responden, dimana responden yang berpenghasilan tinggi dapat memenuhi kebutuhannya akan gizi sehari-hari sehingga gizinya tercukupi. Hal ini sejalan dengan penelitian Rushadi et al di Sukabumi tahun 2014 namun bertolak belakang dengan penelitian Prihanti et al di Kediri tahun 2015.

\section{Pendidikan}

Analisis faktor pendidikan terhadap kejadian TB Paru tidak terdapat pengaruh yang signifikan antara pendidikan rendah dan pendidikan tinggi terhadap terjadinya TB Paru $p=0,184$ $(p>0,05)$ dan selanjutnya diperoleh Odds Ratio $=1,812$ dengan kata lain tidak ada hubungan antara pendidikan dengan penularan TB paru. $\mathrm{Hal}$ ini sejalan dengan penelitian Rushadi et al di Sukabumi tahun 2014 namun bertolak belakang dengan penelitian Muaz di Serang tahun 2014.

\section{Kebiasaan Merokok}

Analisis faktor kebiasaan merokok terhadap kejadian TB Paru terdapat pengaruh yang signifikan antara merokok dan tidak merokok terhadap terjadinya TB Paru $p=0,001 \quad(p<0,05)$ dan selanjutnya diperoleh Odds Ratio = 17,500 . Dengan kata lain peluang terjadinya TB Paru 17,500 kali lebih besar pada responden dengan kebiasaan merokok dibanding responden dengan yang tidak merokok. Dalam penelitian ini, ditemukan bahwa angka kebiasaan merokok sangat tinggi ditemui baik pada responden pria maupun wanita, dikarenakan suhu udara di daerah penelitian tergolong rendah sehingga salah satu cara penduduk untuk menghangatkan tubuh selain dengan 
mengkonsumsi minuman tuak adalah dengan merokok. Hal ini sejalan dengan penelitian Rushadi et al di Sukabumi tahun 2014, juga penelitian Prihanti et al di Kediri tahun 2015 namun bertolak belakang dengan penelitian yang dilakukan Muaz di Serang tahun 2014.

\section{Kepadatan Hunian}

Analisis faktor kepadatan hunian terhadap kejadian TB Paru terdapat pengaruh yang signifikan antara hunian padat dan tidak padat terhadap terjadinya TB Paru $p=0,001 \quad(p<0,05)$ dan selanjutnya diperoleh Odds Ratio = 5,400 . Dengan kata lain peluang terjadinya TB Paru 5,400 kali lebih besar pada responden dengan hunian padat dibanding responden dengan hunian yang tidak padat. Kepadatan hunian merupakan salah satu faktor kejadian TB Paru karena hunian yang padat memperbesar angka penularan TB Paru. $\mathrm{Hal}$ ini sejalan dengan penelitian Prihanti et al di Kediri tahun 2015 namun bertolak belakang dengan penelitian Muaz di Serang tahun 2014.

\section{Pencahayaan Hunian}

Analisis faktor pencahayaan hunian terhadap kejadian TB Paru terdapat pengaruh yang signifikan antara pencahayaan gelap dan pencahayaan terang terhadap terjadinya TB Paru $p=0,034 \quad(p<0,05) \quad$ dan selanjutnya diperoleh Odds Ratio = 3,271. Dengan kata lain peluang terjadinya TB Paru 3,271 kali lebih besar pada responden dengan hunian terang dibanding responden dengan hunian gelap. Pada umumnya kejadian TB Paru salah satu faktor risikonya berupa pencahayaan hunian yang kurang, dikarenkan bakteri M. Tuberculosis akan mati apabila terkena cahaya matahari. Dalam penelitian ini, hunian penderita TB memiliki pencahayaan yang baik yang menandakan bahwa kejadian TB Paru pada penduduk di wilayah ini tidak dipengaruhi oleh pencahayaan huniannya. Hal ini tidak sejalan dengan penelitian Rushadi et al tahun 2014 dan Muaz di Serang tahun 2014.

\section{Jenis Kelamin}

Analisis faktor jenis kelamin terhadap kejadian TB Paru tidak terdapat pengaruh yang signifikan antara jenis kelamin laki-laki dan jenis kelamin perempuan terhadap terjadinya TB Paru $p=1,00 \quad(p>0,05) \quad$ dan selanjutnya diperoleh Odds Ratio $=1,000$. Hal ini sejalan dengan penelitian Prihanti et al di Kediri tahun 2015 namun bertolak belakang dengan penelitian Rushadi et al tahun 2014.

\section{Suku}

Analisis faktor suku terhadap kejadian TB Paru terdapat pengaruh yang signifikan antara suku batak toba dan suku pak-pak terhadap terjadinya TB Paru $p=0,01 \quad(p<0,05)$ dan selanjutnya diperoleh Odds Ratio $=1,000$. Dengan kata lain peluang terjadinya TB Paru 1,000 kali lebih besar pada responden dengan suku toba dibanding responden dengan suku pak-pak.

\section{KESIMPULAN DAN SARAN KESIMPULAN}

Setelah dilakukan penelitian di Sidikalang didapati bahwa kebanyakan pekerjaan adalah tukang becak dan masyarakat Sidikalang memiliki kebiasaan meminum tuak pada malam hari, sehingga kemungkinan terkena penyakit TB Paru melalui kebiasaan meminum tuak pada malam hari sambil berkumpul bersama teman-teman.

Pengaruh umur, status gizi, penghasilan, pendidikan, kebiasaan merokok, kepadatan hunian, pencahayaan hunian, jenis kelamin, suku di Puskesmas Hutarakyat, Kecamatan Sidikalang tahun 2017 adalah sebagai berikut:

1. Umur dewasa dan umur muda tidak berpengaruh terhadap risiko kejadian TB Paru.

2. Status gizi kurang lebih berisiko terhadap peningkatan angka kejadian TB Paru dibandingkan dengan status gizi cukup.

3. Penghasilan rendah lebih berisiko terhadap peningkatan angka kejadian TB Paru dibandingkan dengan penghasilan tinggi.

4. Pendidikan rendah dan tinggi tidak berpengaruh terhadap risiko kejadian TB Paru.

5. Kebiasaan merokok lebih berisiko terhadap peningkatan angka kejadian TB Paru dibandingkan dengan yang tidak merokok. 
6. Kepadatan hunian padat lebih berisiko terhadap peningkatan angka kejadian TB Paru dibandingkan dengan hunian yang tidak padat.

7. Pencahayaan hunian yang terang lebih berisiko terhadap peningkatan angka kejadian TB Paru dibandingkan dengan pencahayaan hunian yang gelap.

8. Jenis kelamin laki-laki dan perempuan tidak berpengaruh terhadap risiko kejadian TB Paru.

9. Suku batak toba lebih berisiko terhadap peningkatan angka kejadian TB Paru dibandingkan dengan suku pak-pak.

\section{DAFTAR PUSTAKA}

Saputra, L. 2013. Buku Saku Harrison Pulmonologi. Tangerang Selatan: Kharisma Publishing Group.

Amin, Z., Bahar, A. 2014. Buku Ajar Ilmu Penyakit Dalam Jilid 1. Jakarta: Interna Publishing.

Depkes RI. 2012. Penyakit menular. Jakarta.

Djojodibroto, R.D. 2016. Respirologi (Respiratory Medicine). Jakarta: Penerbit Buku Kedokteran EGC.

Himawan, A.B., Suharyo, H., Suprihati, 2015. Berbagai Faktor Risiko Kejadian TB Paru Drop Out. Fakultas Kedokteran Undip. Bandung.
Herchline, T. E. 2017. Tuberculosis.

Ibrahim, Ilyas. 2017. Faktor Yang Mempengaruhi Kejadian TB Paru di Wilayah Kota Tidore. FKM Universitas Bumi Hijrah Maluku Utara.vol 2 issue 1. Maluku Utara.

Infodatin. 2016. Tuberkulosis : Temukan Obati Sampai Sembuh. Jakarta.

Isbaniyah, F., dkk.2011. Tuberkulosis Pedoman Diagnosis dan Penatalaksanaan di Indonesia. Jakarta: Perhimpunan Dokter Paru Indonesia.

Kurniasari, R.A.S. Suhartono. Cahyo, K. 2012. Faktor Risiko Kejadian Tuberkulosis Paru di Kecamatan Baturetno Kabupaten Wonogiri. FKM UNDIP. Bandung.

Malelak, M.G.A. Asrifuddin, Afnal. Kandou, G.D.2017. Analisis Faktor Risiko Kejadian TB Paru di RSUD Merauke. Fakultas Kesehatan Masyarakat Universitas Sam Ratulangi. Manado.

Muaz, Faris. 2014. Faktor-faktor yang Mempengaruhi

Kejadian Tuberkulosis Paru Basil Tahan Asam Positif di Puskesmas Kota Serang Tahun 2014. Banten.

Prihanti, G.S.,Sulistiyawati., Ina, R. 2015. Analisis Faktor Risiko Kejadian TB Paru. Fakultas Kedokteran UMM. Volume $11 . \quad$ Malang. 